Edisi Januari - Juni 2020 Vol 19 No 1

\section{JURNAL ILMU PEMERINTAHAN}

\section{nakhoda}

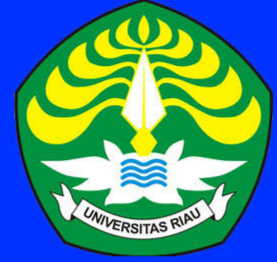

Innovation Hub: Media Kolaborasi Menuju Pemerintahan Daerah Inovatif Herie Saksono

Institusional Building dalam Mengatasi Persoalan Pertambangan Emas Tanpa Izin Di Kabupaten Kuantan Singingi Provinsi Riau

Khotami

Gerakan Masyarakat Tertib Administrasi Kependudukan Melalui Inovasi Pelayanan Lukadesi (Keluarga Berduka Desa Siaga)

Di Kabupaten Sleman D.I Yogyakarta

Hendy Setiawan, Fariza Ikhsanditya

Provinsi 'Istimewa Melayu Riau Kepulauan'

Muchid Albintani, Auradian Marta

Kaderisasi dan Penetapan Calon Legislatif pada Partai Politik (Studi DPD Partai Nasional Demokrat Seram Bagian Barat 2019)

Fandi Ahmad Sintani, Wahab Tuanaya, Marno Wance

Factors of Affect Deliberation of Maguwoharjo

Village Development Planing Sub-District Depok Regency Sleman Yogyakarta Muhammad Rafi, Ulung Pribadi, Fajar Rahmanto

Survey Kepuasan Masyarakat (SKM) pada Badan PendapatanDaerah Kabupaten Bintan

Suherry, Billy Jenawi, Rendra Setyadiharja,

Zamzami A Karim, Firman Setyawan, Rany Angraini

Peran Dewan Perwakilan Daerah (DPD) dalam

Pembentukan Daerah Otonomi Baru (DOB) Di wilayah Provinsi Maluku Utara

Abdul Halil Ibrahim, Bakri La Suhu, Rifjal Tifandy, Marno Wance

MEDIA INFORMASI DAN KOMUNIKASI ILMIAH CIVITAS AKADEMIKA JURUSAN ILMU PEMERINTAHAN

FAKULTAS ILMU SOSIAL DAN ILMU POLITIK

UNIVERSITAS RIAU
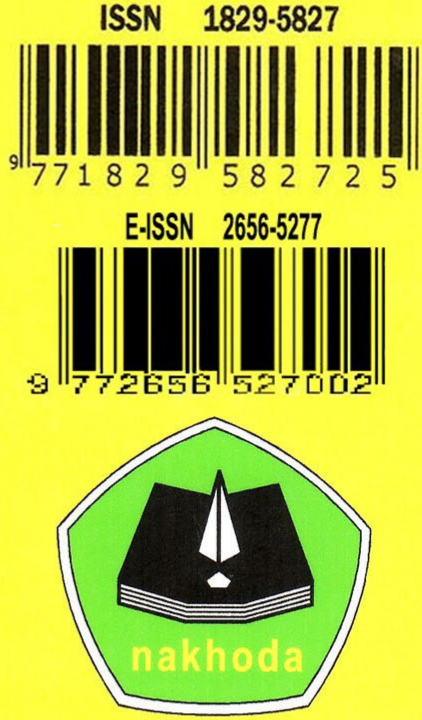

DITERBITKAN OLEH :

LABORATORIUM ILMU PEMERINTAHAN
SEKRETARIAT :

KAMPUS BINA WIDYA SIMPANG BARU

PANAM KM. 12,5 PEKANBARU

(28293) Telp/Fax. (0761)63277 
NAKHODA:

JURNAL

ILMU PEMERINTAHAN
NAKHODA: JURNAL ILMU PEMERINTAHAN

Edisi Januari - Juni 2020 Volume: 19 Nomor: 1

ISSN : 1829-5827 | E-ISSN : 2656-5277

DOI : https://doi.org/10.35967/jipn

https://nakhoda.ejournal.unri.ac.id/index.php/JIPN

INNOVATION HUB: MEDIA KOLABORASI MENUJU PEMERINTAHAN DAERAH INOVATIF

Herie Saksono

Badan Penelitian dan Pengembangan (BPP) Kementerian Dalam Negeri, Jakarta, Indonesia

$1-16$

INSTITUTION BUILDING DALAM MENGATASI PERSOALAN PERTAMBANGAN EMAS

TANPA IZIN DI KABUPATEN KUANTAN SINGINGI PROVINSI RIAU

Khotami

Program Studi Ilmu Pemerintahan, Fakultas IImu Sosial dan IImu Politik Universitas Islam Riau. 17 - 37

Pekanbaru-Indonesia

GERAKAN MASYARAKAT TERTIB ADMINISTRASI KEPENDUDUKAN MELALUI INOVASI

PELAYANAN LUKADESI (KELUARGA BERDUKA DESA SIAGA) DI KABUPATEN SLEMAN

D.I. YOGYAKARTA

Hendy Setiawan ${ }^{1}$, Fariza Ikhsanditya ${ }^{2}$

1,2 Departemen IImu Pemerintahan, Universitas Muhammadiyah Yogyakarta, Yogyakarta,

Indonesia

PROVINSI “ISTIMEWA MELAYU KEPULAUAN RIAU” (GAGASAN PERMULAAN)

Muchid Albintani', Auradian Marta ${ }^{2}$

1,2 Jurusan IImu Pemerintahan, Fakultas IImu Sosial dan IImu Politik, Universitas Riau

KADERISASI DAN PENETAPAN CALON LEGISLATIF PADA PARTAI POLITIK (Studi DPD

Partai Nasional Demokrat Seram Bagian Barat 2019

Fandi Ahmad Sintani ${ }^{1}$, Wahab Tuanaya ${ }^{2}$, Marno Wance ${ }^{3}$

1,2,3 Jurusan IImu Pemerintahan, Universitas Pattimura, Indonesia

$75-90$

FACTORS THAT AFFECT DELIBERATION OF MAGUWOHARJO VILLAGE DEVELOPMENT

PLANNING SUB-DISTRICT DEPOK REGENCY SLEMAN YOGYAKARTA

Muhammad Rafi ${ }^{1}$, Ulung Pribadi2, Fajar Rahmanto ${ }^{3}$

1,2,3 Department of Government Affairs and Administration, Universitas Muhammadiyah

Yogyakarta, Indonesia

SURVEY KEPUASAN MASYARAKAT (SKM) PADA BADAN PENDAPATAN DAERAH

KABUPATEN BINTAN

Suherry ${ }^{1}$, Billy Jenawi², Rendra Setyadihardja ${ }^{3}$, Zamzami A. Karim4,

Firman Setiawan ${ }^{5}$, Rany Angraini ${ }^{6}$

$102-112$

1,2,3,4 STISIPOL Raja Haji, Tanjungpinang, Indonesia

5,6 Bapelitbang, Bintan, Indonesia

PERAN DEWAN PERWAKILAN DAERAH (DPD) DALAM PEMBENTUKAN DAERAH

OTONOMI BARU (DOB) DI WILAYAH PROVINSI MALUKU UTARA

Abdulhalil Hi. Ibrahim ${ }^{1}$, Bakri La Suhu2, Rifjal Tifandy 3 Marno Wance 4

1,2,3 IImu Pemerintahan Universitas Muhammadiyah Maluku Utara, Kota Ternate, Indonesia

$113-127$

${ }^{4}$ IImu Pemerintahan, Universitas Pattimura, Kota Ambon, Indonesia 


\title{
FACTORS THAT AFFECT DELIBERATION OF MAGUWOHARJO VILLAGE DEVELOPMENT PLANNING SUB-DISTRICT DEPOK REGENCY SLEMAN YOGYAKARTA
}

\author{
Muhammad Rafi ${ }^{1}$, Ulung Pribadi ${ }^{2}$, Fajar Rahmanto ${ }^{3}$ \\ ${ }^{1,2,3}$ Department of Government Affairs and Administration, Universitas Muhammadiyah Yogyakarta, Indonesia \\ ${ }^{1}$ m.rafi.psc19@mail.umy.ac.id, ${ }^{2}$ ulungpribadi2@gmail.com, ${ }^{3}$ fajarrahmanto1@gmail.com
}

\begin{abstract}
This research is based on the view of the deliberation forum in the village which should be able to provide dialogue space and community involvement as the subject of development planning, however, the facts that are seen are that the community in Maguwoharjo village is still seen as an object of development planning and the essence of the deliberation forum in the public sphere in the village has not been able to reflect in full by the people in the area. This study aims to analyze the factors that influence deliberation in development planning deliberations and analyze points of weakness in the deliberation process in Maguwoharjo village. The method in this study uses qualitative research methods with data analysis techniques using NVivol2plus software. The results showed that the leadership factor had a percentage of around $36 \%$ in influencing community involvement, the sociocultural factor in the village had a percentage of around $15 \%$ where each figure involved had a dominant view that was very thick with Javanese Culture, from the aspect of communication, had a percentage of around $13 \%$ in conveying the interests of village development, then, local political factors have a percentage of around 13\%, where every participant involved in the village consultation forum has the same interest in development in his area. This study found that the leadership factor was very dominant in influencing the community to be actively involved in the village discussion forum and still found several weaknesses in the deliberation process in the village.
\end{abstract}

\section{Keywords: Deliberation, Planning, Village Development}

\section{INTRODUCTION}

Village development planning is one of the tools for the government and the community to be involved in development. Citizen participation in a broad sense must be supported by the concept of an ideal local culture in the region. Therefore, a sense of community togetherness will increasingly develop towards public policymaking. To achieve this, the deliberative forum in the planning process and as a formulator of policy development in the village must comply with relevant rules so that they can meet the needs of the people in the area(Satries, 2011).

The village has a vital role in national development. Not only because the majority of Indonesians live in villages, but also because villages have a significant influence on national development planning. Village development is a collection of parts of the national development cycle, while national development is a sustainable development planning system that combines all aspects of national life (Rafi et al., 2017). The Village Deliberation is open to the public and not private, and that every villager has the right to be present as a participant in the Village Deliberation. Deliberative democracy gives priority to the use of decision making processes that emphasize deliberation and problem solving with a discussion between the public and the 
state. The aim is to reach an agreement based on the results of the consultation, taking into account various criteria. Everyone's participation is the basis of deliberative democracy (Mardiyanta, 2011).

Village deliberations offer various opportunities for local residents to be involved in discussing the problems being experienced as well as possible development approaches at the village level to be taken to the sub-district level and then to the district and provincial levels. However, the application of this principle is not always consistent with the original goals and priorities of the implementation of development planning (Suroso et al., 2014). As a discussion forum in the village, the Village Development Planning Meeting must be able to involve the community and stakeholders in the village so that all community ideas can be implemented, but in practice, the meeting is currently only influenced by the annual formality agenda, which does not impact public policy in the village(M. Rafi et al., 2017).

According to research (Puspitasari, 2016; Septiana, 2015)Deliberative democracy framed in Musrenbang in the local realm of villages escalates participatory failure in the process, but the village community actually understands deliberative democracy that has been translated into four strategic values; namely participation, inclusiveness, egality, and intersubjectivity. Furthermore, (Mustanir \& Abadi, 2017; Satries, 2011; Tresiana \& Duadji, 2016) Said that the village development planning meeting as a form of deliberative democracy in the village failed to produce policies oriented to the needs of the community due to lack of community participation, lack of policy coherence, and low human resource competence. Therefore, to create deliberative policy products, what needs to be done is to create public debate, because policies and laws are formed through discussion and consultation spaces(Haliim, 2016). Based on the results of tracing the previous studies above, it can be concluded that the study found was focused on how village community participation and community understanding of deliberative democracy in the village, While this research is focused on analyzing the factors that influence deliberation in development planning deliberations and analyzing points weaknesses in the deliberation process in Maguwoharjo village.

In general, village communities have different customs, customs, and cultures in each region. These differences are a consequence of patterns of interaction between citizens, geographical location, diversity of livelihoods, demographic conditions, as well as a cultural heritage that is maintained. Therefore, the results of a study of villages cannot be generalized to other village studies (Puspitasari, 2016). In the view of deliberative democracy, society is not an object, but a subject of democracy. The empirical phenomenon which is the problem of this research is based on the view of deliberation forums in villages that should be able to provide space for dialogue and community involvement as subjects of development planning, however, the fact that the community in Maguwoharjo village is still seen as the object of development planning and the essence of the deliberation forum in public space in the village has not been able to be fully reflected by the people in 
the area. Thus, it is very important to know the factors that influence deliberation in village development planning deliberations.

At present, the village as the smallest element of organizing government political activities is the spotlight that colors the political polemic today, the assumptions about the importance of village government involvement as the executor of development should begin to shift to make the community as the main development subject in the village itself. Therefore, this study has an important meaning for the development of the science of governance, especially in the village administration environment as a government structure that can influence the improvement of national development through deliberation forums that present public opinion.

\section{THEORETICAL FRAMEWORK}

\section{Community Participation in Village Development Planning}

Har Tillar (2009) Explained that participation is evidence of the possibility of increasing democracy through a decentralized system that aims to meet bottom-up planning needs by involving the community in the process of planning and developing village communities. Next, according to Susbandi (2007) Community participation is the involvement of people in classifying problems and potentials that exist within the region, the selection of decisions from solutions that can be considered, the introduction of steps to solve problems and community participation in the process of evaluating changes that occur. The principles of community participation have been set out in the Participatory Approach
Implementation Guidelines compiled by Department for International Development in research Siregar (2016)namely:

a. Scope All individuals and members of all groups affected by the decision or development project phase.

b. The equality that is basically, everyone has the expertise, ability, and initiative and has the right to use this initiative in each phase of dialogue without taking into account the level and structure of each group.

c. Transparency of both parties must be in a position to promote transparent and constructive interaction to build dialogue.

d. For the authority of justice to prevent control, various parties concerned must be able to balance the distribution of power and resources.

e. Various parties have special obligations in each process based on equality of authority and involvement in the decision making process and subsequent actions.

f. The involvement of all parties is inseparable from all the strengths and weaknesses of each party so that with active participation in each phase of the program, the community can share their experiences in solving problems.

Village Development Planning is a system carried out by village government elites, which involves BPD and public stakeholders in a participatory manner for the use and distribution of Village Resources in achieving Village Development goals. The Village Development Planning Meeting is a forum and deliberative democratic process based on village communities. Historically, village deliberations are a tradition of local communities based in Indonesia, Village 
Meetings in the community are a type of village dialogue that has long been known and accepted in the midst of the Javanese environmental community. a community so that citizens' proposals can be fulfilled (Suroso et al., 2014). Broadly speaking, village development planning meetings contain the following meanings:

1. A policy-making process that starts from recognizing community needs to creating development programs.

2. An environmental sustainability policy process, all activities to improve the welfare, security, prosperity, and peace of the community in suburban areas.

3. A community planning that is focused on the problems, desires, hopes, and available resources.

4. A concrete form of citizen involvement and acts as a forum to resolve, reconcile, and harmonize disagreements between the government and nonformal stakeholders, as well as mutual agreement on the objectives for budgeting activities(Mustanir \& Abadi, 2017).

Several factors can influence community participation in village development planning programs, namely:

a. The leadership factor is a factor that influences a person's attitude towards existing social activities. the figure of a leader will be used as a guide and reference for the community to be involved and active in deliberation forums in their area (Siagian, 2016).

b. Socio-cultural factors are differences in characteristics in a region that can be seen from the socio-cultural developments in the community and can influence community involvement in the development planning process. c. The communication factor is the interaction between each group, between citizens and their members, as well as between social systems in society and outside institutions that can increase community involvement and participation in the growth (Suroso et al., 2014).

d. Local political factors in the sense of broad understanding are activities in making, maintaining, and improving general rules that are held to regulate people's lives. whereas in simple terms, local politics is very closely related to the activities of politicians and is related to the pros and cons in social life that can influence community involvement in development planning deliberation forums (Heywood, 2014).

\section{Deliberative Democracy}

Deliberative democracy can be described as a view that places public consideration of free and equal people at the heart of the legitimacy of political and government decision making. As a word, Deliberative comes from Latin, namely, deliberate, which means measuring, evaluating, or deliberation, which means that this language emphasizes the process of obtaining credibility of political decisions produced by the state through evaluation of public consultation, consideration of multi-perspective on the public part, or transparency of deliberation, at least including those who will later bear or be influenced by political decisions (Hardiman, 2009).But as a theory, Hardiman (2004) emphasizing that deliberative democracy focuses more on the system of democratic policy-making and not on the results. That is, the government takes public policy through public trials, public debates, discussions, or 
only determined by a group of people (elites) in the political system without going through a process of deliberation.

From the point of view of deliberative democracy, it is not only the state that can define public policies and other policies, but citizens play a role through active and vocal active organizations, and deliberative democracy also sees that communicative action plays an important role in power. Power can be formed through public discussion forums, which in reality to reach consensus, deliberative democracy must create twoway communication between authority and the public, thereby reducing the hegemony of institutional actors. Residents are therefore expected always to be involved in solving development problems(Asmaul Husna, 2019).

Figure 1. Factors That Affect Deliberation in Village Development Planning

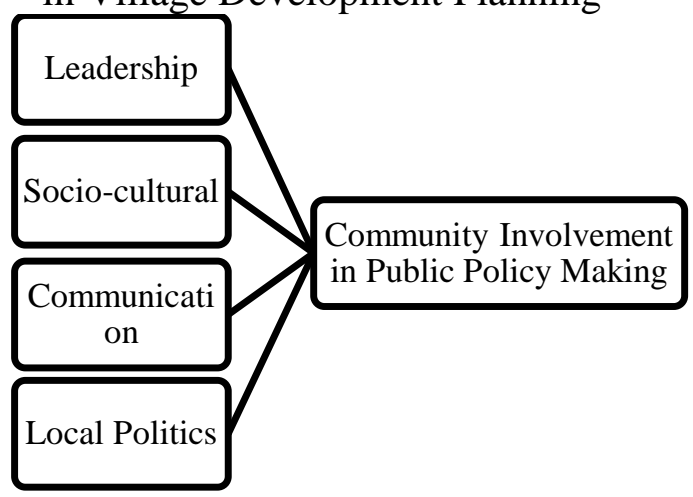

(Source: Author Analysis Result, 2019)

This concept can then explain the factors that influence community involvement in the Maguwoharjo village development planning deliberation process, where people who are dominated by ethnic or cultural similarity must be involved in public policy making.

\section{RESEARCH METHODS}

This research was conducted in the village of Maguworharjo, Depok SubDistrict, Sleman Regency, Yogyakarta, with a qualitative research approach. Qualitative studies are research that seeks to understand phenomena about what is experienced by research subjects such as behavior, how words and language are represented, in a specific natural sense and using various scientific methods (Moleong, 2004). The reason for using this type of qualitative research study because it applies to the recognition of the characteristics or distinguishing characteristics of a group of people, or events that will later be able to find out about what factors can influence in the research (Silalahi, 2010).

The parties involved in the focus of this study were the sub-district government, the village head and his apparatus, the head of the village consultative body, the regional head, women leaders, youth leaders, religious leaders, and education leaders. Data collection techniques used are multimethod strategies that allow to combine several data collection techniques such as interviews, mass media, documentary studies, etc(Albi Anggito, 2018).Next, analyze qualitative data using NVivo software, Welsh (2002)said that Nvivo was relatively easy to use, so it was possible to import documents directly from a word processor easily on the screen. Then, coding stripes can be made and visible in the margins of the document so that researchers can see at a glance which code has been used.

\section{RESULT AND DISCUSSION}

\section{Leadership Factors}


In any government organization or institution, the leadership aspect is crucial, as long as the leadership itself is something that belongs to someone, the individual can move others to take actions or actions with full awareness and confidence (Nurhayati A Yasin \& Abdurrahman Pakaya, 2016). Based on the results of interviews conducted, it can be seen that the leadership of the village head Maguwoharjo influences increasing community involvement in the deliberation forum in the village. The following graph displays leadership factors involving the people in the village.

Figure 2. Leadership Factors in Influencing Community Involvement

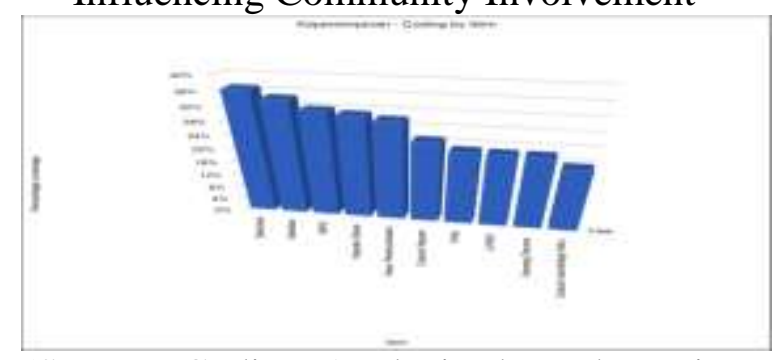

(Source: Coding Analysis through NVivo 12 plus Software, 2019)

Based on the picture above it can be seen that the leadership style of the Maguwoharjo village head in involving the community in public policymaking has the highest percentage of around $36 \%$, where each stakeholder has different views regarding the leadership factor of the village head, as the highest leader in Maguwoharjo village. The village head has a leadership style that is in direct contact with the people in the village, as seen from the results of the interview of researchers to each stakeholder directly involved in the deliberation forum which indicates that the leadership of the village head is already good in creating deliberations in village development planning in Maguwoharjo.This is supported by the role of village communities who are also involved in determining villagedevelopment priorities. Besides, village development planning meetings have been carried out based on applicable rules and regulations.

\section{Sosio-Cultural Factors}

Socio-cultural factors that include norms, values of trust and attitudes can affect community participation in development planning deliberations, not something easy to implement, especially in specific community settings, so that the principles of participation must pay attention to togetherness, grow from the bottom (bottom-up), trust and openness (Mustanir \& Razak, 2017). Based on the results of research that has been done, it can be seen that socio-cultural factors in Maguwoharjo village influence are increasing community involvement in deliberation forums.

Figure 3. Socio-Cultural Factors in Influencing Community Involvement

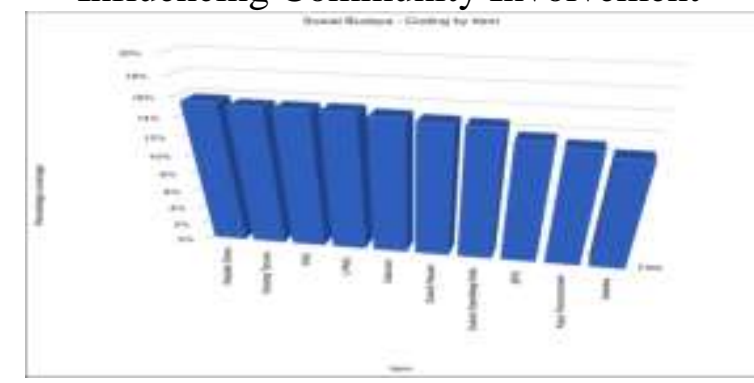

(Source: Coding Analysis through NVivo 12 plus Software, 2019)

Based on the picture above, it can be seen that the socio-cultural factor in Maguwoharjo village has a percentage of around $15 \%$, wherefrom each of the 
figures involved has not many different views related to the social culture in the village. Maguwoharjo Village community is still dominantly very thick with Javanese culture, in relation to the deliberation forum in the village, the contents, forms and ways of citizen participation pay close attention to the socio-cultural aspects, the media used such as shadow puppets, and other arts are always used as a way for the government to invite the community to participate in village development planning meetings, cultural factors greatly affect the lifestyle and mindset of the people of Maguwoharjo Village.

Based on the results of the research analysis, it can be said that the sociocultural aspects of the village of Maguwoharjo can influence community involvement in public policymaking in the village. Still, this aspect is not the most dominant factor in shaping the community itself. It can be seen from the percentage level, which is still in the classification, is not too high when compared to other aspects that influence.

\section{Communication Factors}

The role of communication becomes vital for all participants in the development process to raise awareness, provide information, and advance the community. The dimension of communication is one of the factors that determine the success of growth, especially relating to community involvement (Sulaiman et al., 2015). Community activeness in deliberation forum is an essential factor to be able to influence public policies to be achieved, and the following graph is the results of researchers' analysis of communication factors in the Maguwoharjo village development planning discussion:

Figure 4. Communication Factors in Influencing Community Involvement

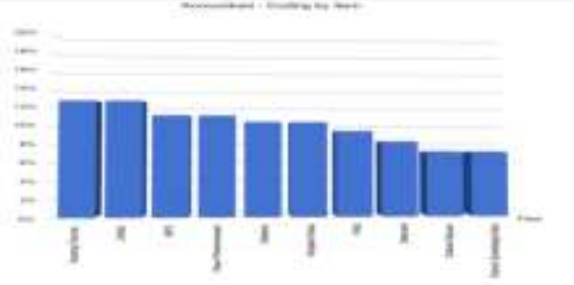

(Source: Coding Analysis through NVivo 12 plus Software, 2019)

In the picture above shows that the role of the communication aspect in the deliberation forum in Maguwoharjo Village has a percentage of around 13\%, the proposals of community development brought by each region have substance and lead to the development priorities of the Maguwoharjo village. Participants involved in the Village Development Deliberation Dialogue are The Subdistrict Government, Village Heads, and their Apparatus, Community Leaders, Religious Leaders, Educational Leaders, Regional Heads, Chairperson of Community Associations, Chairperson of Neighborhood Associations, Management of Youth Organizations, Administrators of Women's Groups, Health Figures, and Village Community Empowerment Institutions. The active communication carried out by stakeholders in each village area will determine community participation in publicpolicymaking in the village, so that it can be a participatory development plan and support the creation of the quality of deliberative democratic forums in Maguwoharjo villages.

\section{Local Political Factors}


According tolbrahim (2013) The local political context is related to the conception of political systems and the dynamics of local politics, the characteristics of the community that local heterogeneity will color and influence the understanding of local politics that occur, all components of society will dynamically interact in the context of the role, capacity and capability will contribute specifically in the process the administration. The local political aspects of Maguwoharjo village can also influence community participation in the deliberation forum in the village, and the following is a graphical display of the results of researchers' analysis of local political factors in Maguwoharjo village:

Figure 5. Local Political Factors in Influencing Community Involvement

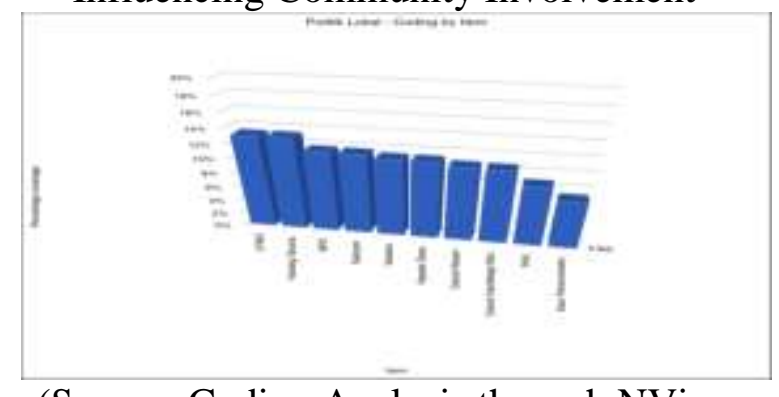

(Source: Coding Analysis through NVivo 12 plus Software, 2019)

In the picture above, it can be seen that the local political factor has a percentage of around $13 \%$, where each participant involved in the village development planning deliberation forum has a strong awareness and has a common interest in development in their respective regions, which must be realized immediately. In addition, the Government of Maguwoharjo Village has a unique way of increasing the involvement of village communities, namely determining the development priorities of the
Maguwoharjo village can be done and realized by considering the presence and delivery of the aggregation of interests of each delegation present, that is, if there are representatives of regions that are not present In this forum.

However, the development proposals in each region were very urgent, no delegation was present and presented their arguments in the region, the recommendations produced in the previous regional deliberations could not be prioritized for village development.This certainly makes the community think to be actively involved in the development planning of Maguwoharjo village. Furthermore, the Maguwoharjo village development planning deliberation process indicated that local political factors influenced increasing community involvement in village development programs.

Based on the results of the above research, it can be seen that the leadership factor dramatically influences the community to be actively involved in the development planning program. This is the theory used by the researcher (Siagian, 2016) This says that a person's leadership figure is a dominant aspect of increasing individual involvement in existing community activities. This can be seen from the leadership factor of Maguwoharjo village head, who has the highest percentage of around $36 \%$ in influencing community involvement. Furthermore, socio-cultural factors according to research (Mustanir \& Razak, 2017) Whichincludes norms, values of trust and attitudes can influence community participation in development planning deliberations, where the principles of participation must pay attention to togetherness that grows from 
the bottom (bottom-up) and trust and openness, this is seen in the socio-cultural factors inherent in the village Maguwoharjo such as shadow puppets and other arts and has an influence on community participation with a percentage of about $15 \%$.

Then, the communication factor, according to research. (Sulaiman et al., 2015) That is, intensive interactions carried out by each group, between citizens and their members, as well as between social systems in society and outside institutions capable of increasing community involvement and participation in development, the results of this study support the theory used, this can be seen from the communication aspect of the deliberation forum in Maguwoharjo Village which has a percentage of around $13 \%$, although it is not a dominant factor in the deliberation forum, however, the activeness of the communication carried out by the actors involved representing each region will determine community participation in public policymaking in the village. The 4th (four) factor that can influence community involvement in public policymaking is the local political aspect according to (Ibrahim, 2013) Existing in the village and have a percentage of about $13 \%$, this is seen from the involvement of participants in the village development planning deliberation forum, in general, the community has a strong awareness and have interests brought from each region.

Based on the results of interviews that we have done, this research found several findings in the deliberation process of Maguwoharjo village development planning which are listed in the following table:

\section{Table 1. Analysis of the Deliberation Process in Maguwoharjo Village}

\begin{tabular}{|c|c|c|c|c|}
\hline Information & $\begin{array}{c}\text { Substance } \\
\text { Balance }\end{array}$ & Diversity & Awareness & $\begin{array}{c}\text { Fair } \\
\text { Consideration }\end{array}$ \\
\hline $\begin{array}{l}\text { Participants } \\
\text { in the } \\
\text { Deliberation } \\
\text { already } \\
\text { have access } \\
\text { to } \\
\text { information } \\
\text { relevant to } \\
\text { the problem } \\
\text { to be } \\
\text { discussed }\end{array}$ & $\begin{array}{c}\text { No } \\
\text { argument } \\
\text { was found } \\
\text { that was } \\
\text { answered } \\
\text { by one of } \\
\text { the parties } \\
\text { who had a } \\
\text { different } \\
\text { perspective }\end{array}$ & $\begin{array}{c}\text { The main } \\
\text { position of } \\
\text { community } \\
\text { proposals } \\
\text { brought by } \\
\text { Padukuhan } \\
\text { is not able } \\
\text { to be } \\
\text { maintained } \\
\text { in public } \\
\text { space }\end{array}$ & $\begin{array}{l}\text { The } \\
\text { arguments } \\
\text { being } \\
\text { debated do } \\
\text { not } \\
\text { describe } \\
\text { the } \\
\text { benefits to } \\
\text { the } \\
\text { community }\end{array}$ & $\begin{array}{l}\text { The decision } \\
\text { made has } \\
\text { involved the } \\
\text { community } \\
\text { and does not } \\
\text { look at the } \\
\text { background } \\
\text { that conveys } \\
\text { their } \\
\text { aspirations }\end{array}$ \\
\hline
\end{tabular}

Source: Researchers Analysis Results 2020

\section{CONCLUSION}

From the results of this discussion, it can be concluded that the factors that can influence community involvement in the Maguwoharjo village development planning deliberation forum are leadership factors which have the highest percentage of $36 \%$, socio-cultural factors around $15 \%$, communication factors $13 \%$, and political factors around $13 \%$. These 4 (four) factors are able to influence community participation and make the community active in development forums in the village.The limitation of this study is related to the limitations of researchers in determining and selecting stakeholders involved in village deliberations, and then researchers find it difficult to measure the quality of deliberation in village development planning deliberations, according to $\mathrm{F}$. Budi Hardiman's deliberative democratic theory.Furthermore, the weakness of this research study is the lack of case studies presented so that no significant differences are seen with prior research. Then, the researcher really hopes for further research 
to identify better and analyze the factors that influence community involvement in the deliberation forum in the village.

\section{REFERENCES}

Albi Anggito, J. S. (2018). Metodologi Penelitian Kualitatif. Jawa Barat: CV Jejak.

Asmaul Husna. (2019). Melawan dominasi penguasa: wacana demokrasi deliberatif untuk indonesia. Jurnal Ilmu Komunikasi, 5(1), 1-13.

Haliim, W. (2016). Demokrasi Deliberatif Indonesia : Konsep Partisipasi Masyarakat Dalam Membentuk Demokrasi Dan Hukum Yang Responsif. Jurnal Masyarakat Indonesia, 42(1), 19-30.

Hardiman, F. B. (2004). Demokrasi Deliberatif: Model Untuk Indonesia Pasca Soeharto. Yogyakarta: Majalah Basis.

Hardiman, F. B. (2009). Menimbang Negara Hukum Dan Ruang Publik Dalam Teori Diskursus Jurgen Habermas. Yogyakarta: Kanisius.

Heywood, A. (2014). POLITIK (Ke-4; A. L. Lazuardi, ed.). Yogyakarta: Pustaka Pelajar.

Ibrahim, A. (2013). Dinamika Politik Lokal Konsep Dasar dan Implementasinya. Bandung: Mandar Maju.

M. Rafi, Baskoro Wicaksono, I. (2017). Deliberation in Planning Development in the Village of Renak Dungun Subdistrict Pulau Merbau Regency Kepulauan Meranti Year 2014-2015. Atlantis Press International Conference on Democracy, Accountability and Governance, 163(November 2017),
290-295.

https://doi.org/10.2991/icodag-

17.2017.56

Mardiyanta, A. (2011). Kebijakan Publik Deliberatif: Relevansi dan Tantangan Implementasinya. Jurnal Media Masyarakat, Kebudayaan Dan Politik, 24(3), 261-271.

Moleong, J. L. (2004). Metode Peneltian Kualitatif. Bandung: PT. Remaja Rosdakarya.

Mustanir, A., \& Abadi, P. (2017). Partisipasi Masyarakat Dalam Musyawarah Rencana Pembangunan Di Kelurahan Kanyuara Kecamatan Watang Sidenreng Kabupaten Sidenreng Rappang. Jurnal Politik Profetik, 5(2), 247-261.

Mustanir, A., \& Razak, M. R. R. (2017). Nilai Sosial Budaya Pada Partisipasi Masyarakat Etnik Towani Tolotang Dalam Musyawarah Rencana Pembangunan. Prosiding Konferensi Nasional Ke-6 Asosiasi Program Pascasarjana Perguruan Tinggi Muhammadiyah Aisyiyah (APPPTMA), (October), 1-7.

Nurhayati A Yasin, Abdurrahman Pakaya, L. I. R. (2016). Gaya Kepemimpinan Kepala Desa Dalam Memberikan Pelayanan Kepada Masyarakat di Desa Tolinggula Pantai Kecamatan Tolinggula. Jurnal Ilmu Administrasi, $5(1)$.

Puspitasari. (2016). Pemahaman Demokrasi Deliberatif Dalam Perspektif Masyarakat Desa Studi Kasus Padukuhan Kalimanggis Morangan Desa Sindumartani Ngemplak Sleman DIY. Jurnal Mahasiswa UGM, 3(2), 11-21.

Satries, W. I. (2011). Mengukur Tingkat Partisipasi Masyarakat Kota Bekasi 
Dalam Penyusunan APBD melalui Pelaksanaan Musrenbang 2010. Jurnal Kybernan, 2(2), 89-130.

Septiana, R. (2015). Deliberative Democracy dalam Masyarakat Desa (Studi Implementasi Musyawarah Rencana Pembangunan Sebagai Instrumen Deliberative Democracy di Desa Pandowoharjo Padukuhan Tlacap-Grojogan Kecamatan Sleman Kabupaten Sleman DI Yogyakarta). Jurnal Mahasiswa UGM, 2(1), 1-10.

Siagian, S. P. (2016). Teori dan Praktek Kepemimpinan. Jakarta: Rineka Cipta.

Silalahi, U. (2010). Metode Penelitian Sosial. Bandung: Refika Aditama.

Siregar, A. Z. (2016). Social Motivation And Peoples Participation In Development Of Rural Development In District Of West Of Nias Province North Sumatra. International Journal of Scientific \& Technology Research, 5(10), 47-58.

Sulaiman, A. I., Lubis, D. P., Susanto, D., \& Purnaningsih, N. (2015). Komunikasi Stakeholder dalam Musyawarah Perencanaan Pembangunan (Musrenbang). MIMBAR, Jurnal Sosial Dan Pembangunan, 31(2), 367. https://doi.org/10.29313/mimbar.v31i 2.1467

Suroso, H., Hakim, A., \& Noor, I. (2014). Faktor-Faktor yang Mempengaruhi Partisipasi Masyarakat dalam Perencanaan Pembangunan di Desa Banjaran Kecamatan Driyorejo Kabupaten Gresik. WACANA, Jurnal Sosial Dan Humaniora, 17(1), 7-15. Retrieved from http://www.wacana.ub.ac.id/index.ph p/wacana/article/view/290
Susbandi, A. R. (2007). Perencanaan Partisipatoris Berbasis Aset Komunitas: dari Pemikiran Menuju Penerapan. Depok: Fisip IU Press.

Tillar, H. (2009). Kekuasaan dan pendidikan: Manajemen pendidikan nasional dalam pusaran kekuasaan. Jakarta: Rineka Cipta.

Tresiana, N., \& Duadji, N. (2016). Kegagalan pemaknaan "Lembaga Musawarah Perencanaan dan Pembangunan Desa" dalam mewujudkan Deepening Democracy. Jurnal Masyarakat Kebudayaan Dan Politik, 29(4), 191-203.

Welsh, E. (2002). Dealing with Data: Using NVivo in the Qualitative Data Analysis Process. Forum: Qualitative Social Research Sozialforschung, 3(2), 9 . 